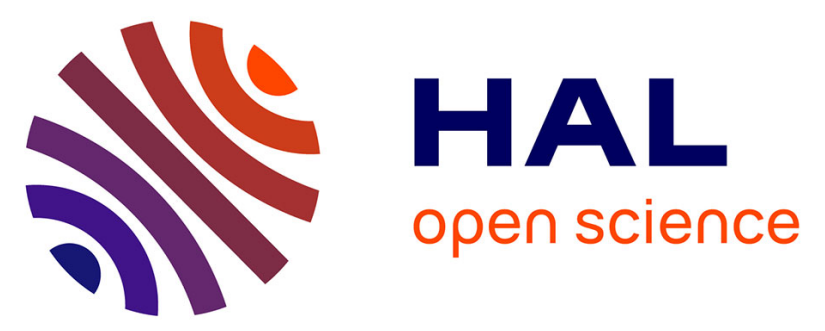

\title{
Synthesis, Resolution, and Absolute Configuration of Chiral Tris(2-pyridylmethyl)amine-Based Hemicryptophane Molecular Cages
}

\author{
Dawei Zhang, Benjamin Bousquet, Jean-Christophe Jean, Delphine Pitrat, \\ Marion Jean, Nicolas Vanthuyne, Laure Guy, Jean-Pierre Dutasta, Alexandre \\ Martinez
}

\section{To cite this version:}

Dawei Zhang, Benjamin Bousquet, Jean-Christophe Jean, Delphine Pitrat, Marion Jean, et al.. Synthesis, Resolution, and Absolute Configuration of Chiral Tris(2-pyridylmethyl)amine-Based Hemicryptophane Molecular Cages. Journal of Organic Chemistry, 2017, 82 (12), pp.6082-6088. 10.1021/acs.joc.7b00559 . hal-01682759

\section{HAL Id: hal-01682759 https://hal.science/hal-01682759}

Submitted on 20 Apr 2018

HAL is a multi-disciplinary open access archive for the deposit and dissemination of scientific research documents, whether they are published or not. The documents may come from teaching and research institutions in France or abroad, or from public or private research centers.
L'archive ouverte pluridisciplinaire HAL, est destinée au dépôt et à la diffusion de documents scientifiques de niveau recherche, publiés ou non, émanant des établissements d'enseignement et de recherche français ou étrangers, des laboratoires publics ou privés. 


\title{
Synthesis, Resolution, and Absolute Configuration of Chiral Tris(2- pyridylmethyl)amine-Based Hemicryptophane Molecular Cages
}

\author{
Dawei Zhang, ${ }^{\dagger}$ Benjamin Bousquet, ${ }^{\dagger}$ Jean-Christophe Mulatier, ${ }^{\dagger}$ Delphine Pitrat, ${ }^{\dagger}$ Marion Jean, ${ }^{\ddagger}$

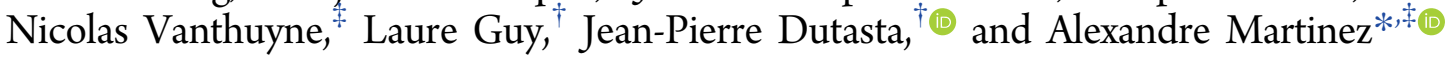 \\ ${ }^{\dagger}$ Laboratoire de Chimie, École Normale Supérieure de Lyon, CNRS, UCBL, 46 allée d'Italie, F-69364 Lyon, France \\ ${ }^{\ddagger}$ Aix Marseille Univ, CNRS, Centrale Marseille, iSm2, Marseille, France
}

\begin{abstract}
The synthesis, characterization, and chiroptical properties of a new class of hemicryptophane cages combining a cyclotriveratrylene unit and a tris(2-pyridylmethyl)amine (TPA) moiety are reported. Changing the linkers between these two units allows for the modification of the size and shape of the cavity. The synthesis is straightforward and efficient, providing gram-scale of cage compounds. The racemic mixture of each hemicryptophane host can be readily resolved by chiral HPLC, giving an easy access to the enantiopure molecular cages of which absolute configurations have been assigned by ECD spectroscopy. These new hemicryptophanes are available chemical platforms ready to use for various purposes due to the versatile metal complexation properties of the TPA unit. A $\mathrm{Zn}$ (II)@hemicryptophane complex has been obtained and used as a heteroditopic host for the selective recognition of zwitterionic guests.
\end{abstract}

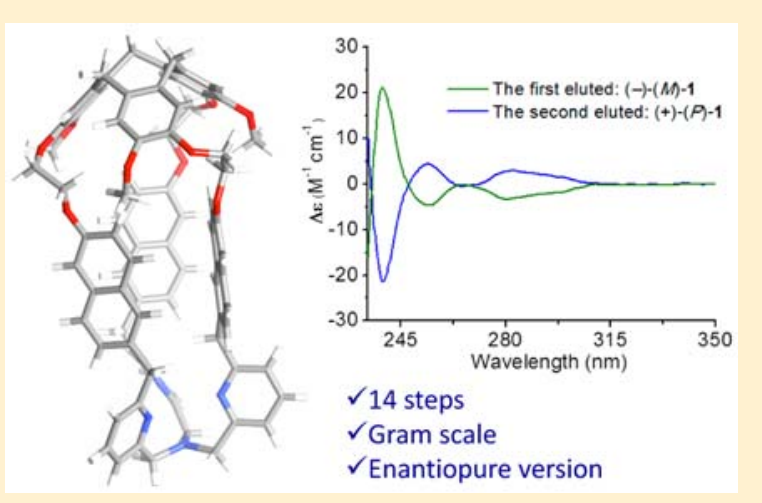

\section{INTRODUCTION}

Molecular cages have attracted considerable attention in the last two decades, leading to important applications in recognition, catalysis, separation, and reactive species stabilization. ${ }^{1}$ In particular, biomimetic chiral cages arouse a growing interest because of the important role of chirality in nature. ${ }^{2}$ One prominent example is substrate binding and transformation by enzymes, displaying high chemoselectivity, regioselectivity, and stereospecificity. ${ }^{3}$ Among the chiral cages, hemicryptophanes, which combine a cyclotriveratrylene (CTV) unit with another $C_{3}$-symmetric moiety, exhibit remarkable properties in molecular recognition and supramolecular catalysis. ${ }^{1 a}$ The promising applications of hemicryptophanes benefit from the rigid bowl shape of the inherently chiral CTV unit as well as the feature of variability and easy functionalization of the other $C_{3}$ symmetrical moiety.

To construct novel hemicryptophane scaffolds, tripodal building blocks, such as tris(2-aminoethyl)-amine (tren $)^{4}$ and trialkanolamine units, ${ }^{5}$ have been attached to the CTV unit. The usefulness and easy availability should be considered when choosing this $C_{3}$-symmetric group. In this regard, the tris(2pyridylmethyl)amine (TPA) unit appears promising. Indeed, TPA ligand is widely used in coordination chemistry and can bind with various metals, such as $\mathrm{Fe}^{6}{ }^{6} \mathrm{Cu},{ }^{7} \mathrm{Zn},{ }^{8} \mathrm{Co},{ }^{9} \mathrm{Mn},{ }^{10}$ $\mathrm{Ru},{ }^{11} \mathrm{Rh}^{12}{ }^{12} \mathrm{Ni}^{13}$ and Ln. ${ }^{14}$ The resulting complexes have been extensively used in recognition, ${ }^{15}$ catalysis, ${ }^{6,7,10 b, 11 b, 12}$ chiroptical molecular switches, ${ }^{16}$ and enantiomeric excess (ee) determination. $^{8 \mathrm{a}, \mathrm{b}, 17}$ For instance, the $\left[\mathrm{Fe}-(\mathrm{TPA})(\mathrm{MeCN})_{2}\right]$ $\left(\mathrm{ClO}_{4}\right)_{2}$ complex combined with photocatalyst riboflavin tetraacetate has been used as a readily accessible and efficient catalytic system for the visible-light-driven aerobic $\mathrm{C}-\mathrm{H}$ bond oxidation of alkyl benzene to ketones and carboxylic acids. ${ }^{6 a}$ The copper complexes of TPA derivatives have been widely used to catalyze the reactions of atom transfer radical cyclization (ATRC), ${ }^{\text {a }}$ atom transfer radical addition (ATRA), ${ }^{7 \mathrm{~b}}$ and atom transfer radical polymerization (ATRP). ${ }^{7 \mathrm{c}}$ Moreover, Anslyn and Giulia et al. adopted $\mathrm{Zn}$ (II) or $\mathrm{Cu}$ (II) complexes of TPA derivatives for rapid determination of ee of alcohols, carboxylic acids, amines, and amino acids. $^{8 \mathrm{a}, \mathrm{b}, 17}$ This application originates from the propeller-like arrangement of TPA ligands around the metal center. The handedness of the helicity of the TPA analogues can also be controlled by the presence of a stereogenic center in the ligand backbone, which realizes redox-triggered chiroptical switches, as reported by the group of Canary.

In line with the versatile nature of TPA complexes and their potential applications, we hereby report on the design and synthesis of a class of TPA-based hemicryptophanes (Figure 1). A Zn(II)@hemicryptophane complex has also been obtained and used for the selective encapsulation of zwitterionic guest. The racemic hemicryptophane ligand can be readily resolved by chiral HPLC to give the enantiopure form in relatively large scale. Electronic circular dichroism (ECD) spectroscopy was used to determine the absolute configuration of each hemicryptophane enantiomer. To the best of our knowledge, 


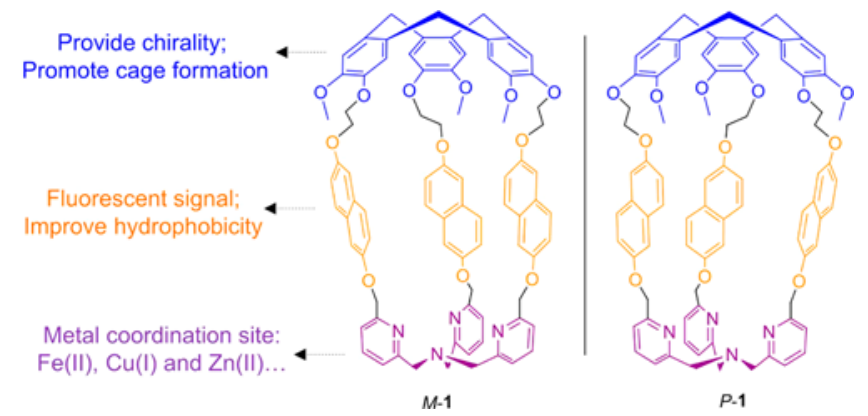

Figure 1. Structure of the new enantiopure TPA-based hemicryptophanes.

the synthesis of enantiopure TPA-based cage molecules is unprecedented, and these enantiopure hemicryptophanes are promising chemical platforms capable of complexation of various metals for different purposes and applications.

\section{RESULTS AND DISCUSSION}

The structures of the enantiomeric hemicryptophanes $M-1$ and P-1 (Figure 1) present the following features: (i) first, the bowlshaped CTV unit allows the formation of a well-defined chiral cavity; (ii) the naphthalene fluorophores, used as hydrophobic "walls" connecting the TPA and CTV units, confer fluorescence properties to the host; (iii) as mentioned above, the TPA moiety is able to coordinate with various metals giving rise to chemical platforms for further applications. Two synthesis routes can be followed to obtain hemicryptophane compounds: (i) the $[1+1]$ coupling reaction between a CTV moiety and another $C_{3}$-symmetrical unit to afford the expected cage or (ii) the triple macrocylization reaction to build the CTV core in the last step of the synthesis. ${ }^{\text {la }}$ We anticipated that the protonation of the TPA unit in formic acid could lead to some preorganization of the precursor for the cyclization; thus, we decided to adopt the second strategy, ${ }^{1, \mathrm{~b}, \mathrm{ba}}$ and we first prepared the TPA-trichloride $\mathbf{8}$ (Scheme 1 ). ${ }^{18}$

Starting from 2,6-pyridinedicarboxylic acid 2, 2,6-pyridinedicarboxylate 3 was quantitatively prepared in two successive steps: chloroformylation with thionyl chloride under reflux followed by esterification with $\mathrm{MeOH}$ at room temperature. The reduction of one ester group in 3 by 1.0 equiv of $\mathrm{NaBH}_{4}$ in $\mathrm{CH}_{2} \mathrm{Cl}_{2} / \mathrm{MeOH}$ afforded alcohol 4 in $56 \%$ yield. Bromide 5 was then obtained quantitatively by bromination of 4 with $\mathrm{PBr}_{3}$ at $\mathrm{rt}$. The addition of an ammonia solution to 5 in the presence of $\mathrm{K}_{2} \mathrm{CO}_{3}$ under reflux for 1 day gave the TPA-triester 6 in $34 \%$ yield. The synthesis of trichloride 8 was achieved by reduction of 6 with an excess of $\mathrm{NaBH}_{4}$ followed by chlorination using thionyl chloride, with an overall yield of $45 \%$ (Scheme 1 ).
In order to prepare the hemicryptophane precursor 13, the naphtol derivative $\mathbf{1 2}$ was synthesized according to the pathway described in Scheme 2. First, 2,6-dihydroxynaphthalene was monoallyl-protected via its reaction with 1.0 equiv of allyl bromide in acetone in the presence of $\mathrm{K}_{2} \mathrm{CO}_{3}$ to give allyloxynaphtol 9 in $29 \%$ yield. Then, 9 reacted with compound 10, obtained in three steps as described previously, ${ }^{5 a}$ in the presence of $\mathrm{Cs}_{2} \mathrm{CO}_{3}$ in DMF at $80{ }^{\circ} \mathrm{C}$ to give 11 in $78 \%$ yield. Compound 11 was subsequently deprotected using $\mathrm{Pd}(\mathrm{II})$ complex in a $\mathrm{H}_{2} \mathrm{O} / \mathrm{THF}$ mixture at $80{ }^{\circ} \mathrm{C}$ to generate the naphtol derivative 12 in $88 \%$ yield.

Hemicryptophane precursor 13 was prepared in one step ( $98 \%$ yield) by heating a solution of 8 and 12 in DMF at $90{ }^{\circ} \mathrm{C}$ for 3 days in the presence of $\mathrm{Cs}_{2} \mathrm{CO}_{3}$ as a base (Scheme 3). The intramolecular cyclization of 13 , first performed in formic acid, led to low yields because of purification issues: several side products were very difficult to separate from the cage compounds. Finally, the use of stoichiometric amounts of Lewis acid $\mathrm{Sc}(\mathrm{OTf})_{3}$ in $\mathrm{CH}_{3} \mathrm{CN}$ at $65{ }^{\circ} \mathrm{C}$ provided rachemicryptophane $( \pm)-1$ with a yield of $49 \%$.

Given the modular feature of this synthetic pathway, we decided to change the naphtyl linkers to phenyl ones in order to prepare the hemicryptophane analogue $( \pm)-16$ presenting a smaller cavity (Scheme 4). Compound 14 was first obtained following the known procedure. ${ }^{5 a}$ The hemicryptophane precursor 15 was synthesized from 14, following a synthetic route similar to that used to get 13 from 12 . The macrocyclization of $\mathbf{1 5}$ in formic acid afforded the racemic mixture ( \pm )-16 in $90 \%$ yield. Remarkably, hemicryptophane $\mathbf{1 6}$ was easily isolated by simple precipitation in $\mathrm{CH}_{2} \mathrm{Cl}_{2} / \mathrm{Et}_{2} \mathrm{O}$ without the need for column chromatography purification. The preorganization of the precursor of cyclization in formic acid can account for the remarkable yield obtained. Moreover, because the yields of the previous steps were relatively high, gram-scale synthesis of $( \pm)-\mathbf{1 6}$ could be achieved. This constitutes an important step for the future development of this class of host compounds as sensors or catalysts, considering the common limitation related to the difficulty of accessing cage compounds on a large scale. ${ }^{1 \mathrm{a}}$

The ${ }^{1} \mathrm{H}$ NMR spectra of $( \pm)-1$ and $( \pm)-16$ indicate that the molecules are, on average, of $C_{3}$ symmetry in solution (Figure 2). They display the usual features of the structure of the CTV unit, i.e., two singlets for the aromatic protons, one singlet for the $\mathrm{OCH}_{3}$ groups, and the characteristic $\mathrm{AB}$ system for the $\mathrm{ArCH}_{2}$ bridges. ${ }^{1 \mathrm{a}, \mathrm{b}}$ The protons on aromatic TPA and linkers and the multiplets for the $\mathrm{OCH}_{2}$ linkers in each cage were carefully assigned by 2D NMR experiments (see the Supporting Information).

To test the metal coordination ability of the TPA units of hemicryptophanes, we prepared the zinc complex $\mathrm{Zn}(\mathrm{II}) @ 16$

Scheme 1. Synthesis of TPA-Trichloride 8

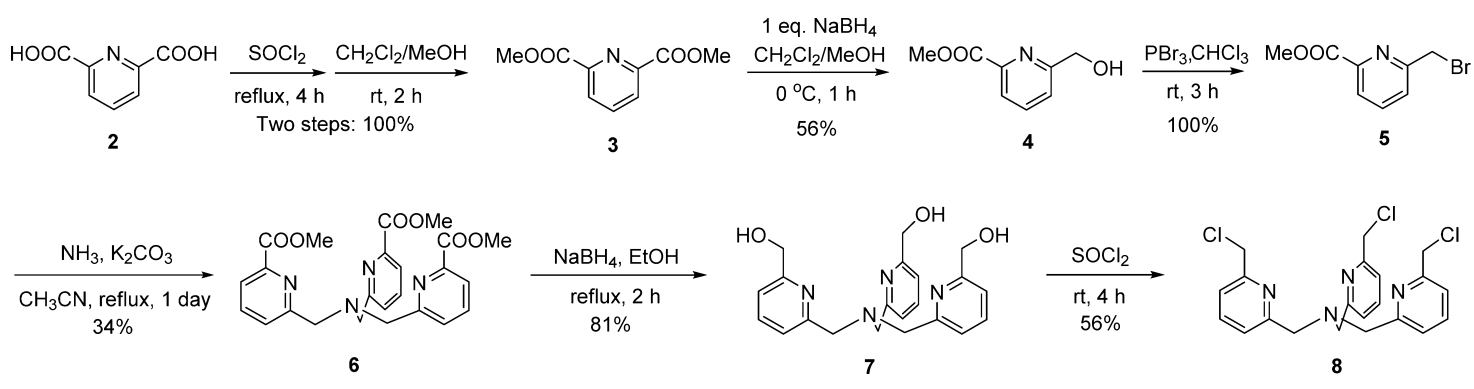




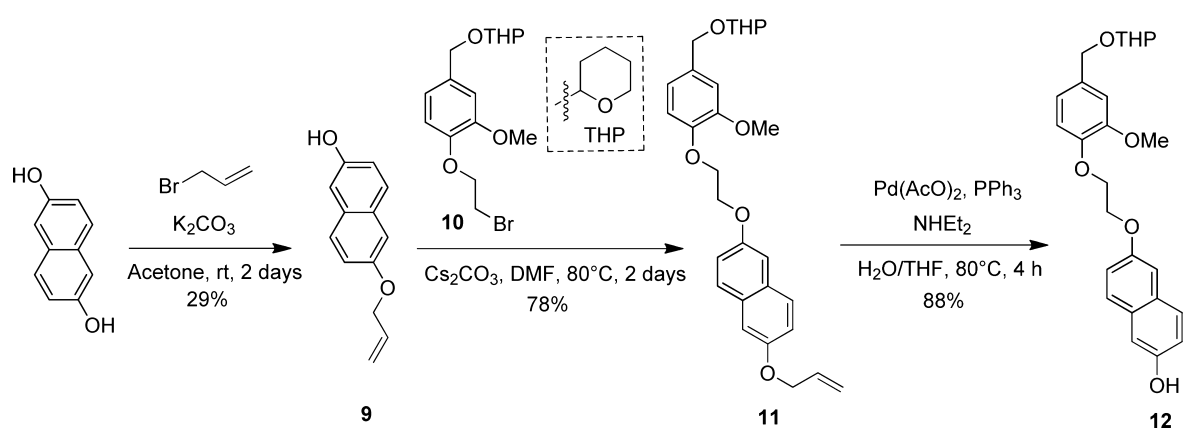

Scheme 3. Synthesis of the Racemic Mixture of Hemicryptophane ( \pm )-1

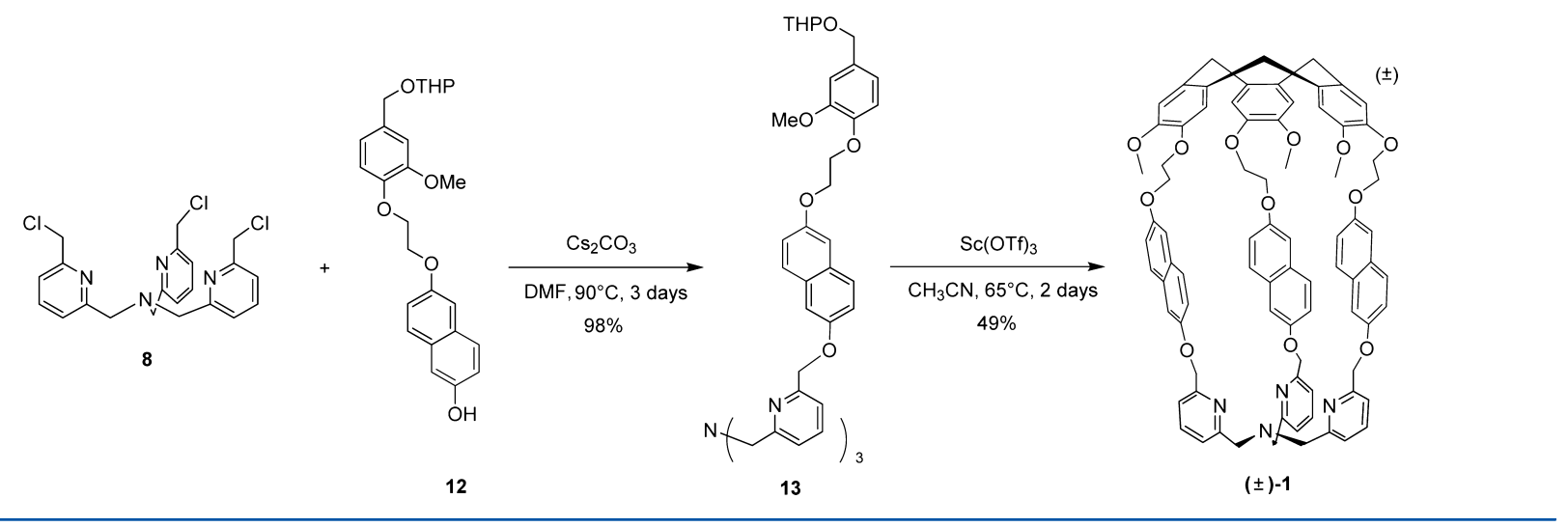

Scheme 4. Synthesis of the Racemic Mixture of Hemicryptophane $( \pm)-16$
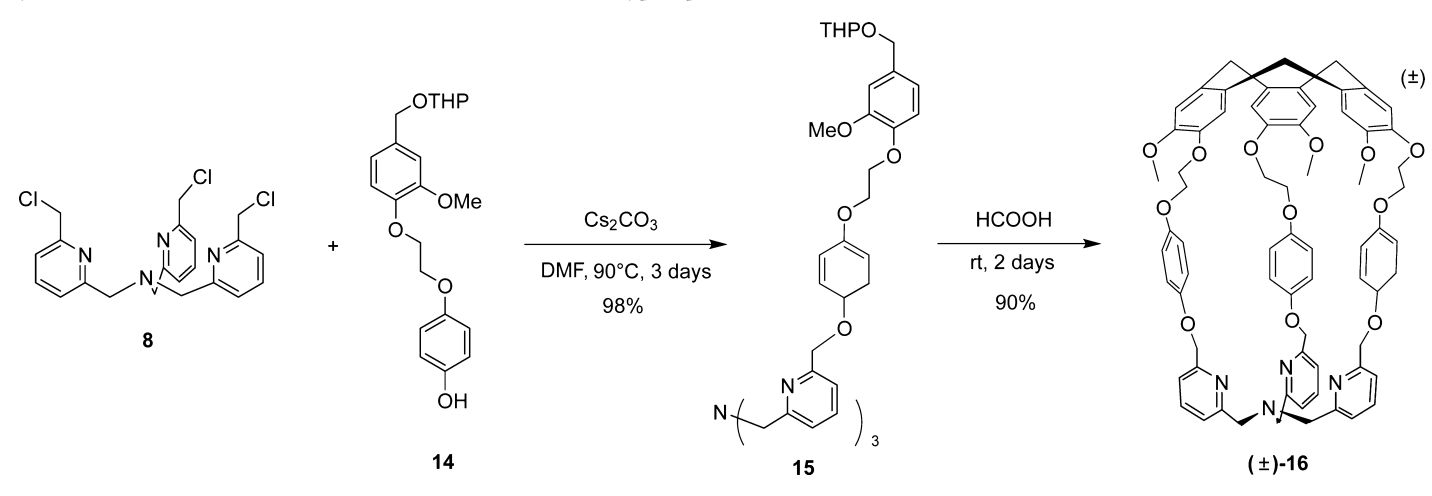

$( \pm)-16$

by mixing the ligand 16 and $\mathrm{Zn}\left(\mathrm{ClO}_{4}\right)_{2}$ in a $\mathrm{CHCl}_{2} / \mathrm{CH}_{3} \mathrm{OH}$ mixture (1/1, v/v) (Scheme 5). The pure Zn(II)@16 complex gradually precipitates within $4 \mathrm{~h}$ and was fully characterized in DMSO- $d_{6}$ by a series of NMR experiments (see the Supporting Information) and HRMS spectroscopy. The ${ }^{1} \mathrm{H}$ NMR spectrum of $\mathrm{Zn}(\mathrm{II}) @ 16$ is consistent with that of the previously reported $\mathrm{Zn}(\mathrm{II}) @$ hemicryptophane complex bearing tren unit ${ }^{4 \mathrm{~b}}$ and exhibits complicated and broad signals because of the conformational rigidification of the whole structure induced by the metal complexation (Figure S11).

The heteroditopic character of the new complex prompted us to test its recognition properties toward zwitterionic guests. ${ }^{19}$ As shown in Figure 3, upon stepwise addition of zwitterionic G1 to a DMSO- $d_{6} / \mathrm{D}_{2} \mathrm{O}(80 / 20, \mathrm{v} / \mathrm{v})$ solution of $\mathrm{Zn}$ (II)@16, several signals in the ${ }^{1} \mathrm{H}$ NMR spectrum shifted gradually, indicating that the host-guest complexation is fast on the NMR time scale. Previously, our group also reported three other heteroditopic hemicryptophanes which showed high selectivity toward either taurine $\mathbf{G} 2^{19 a, b}$ or choline $\mathbf{G} 3^{19 c}$
(Figure 3). However, in the present case, no obvious change of the ${ }^{1} \mathrm{H}$ NMR spectra of $\mathrm{Zn}$ (II)@16 was observed after addition of G2 or G3, highlighting the selectivity of the new host and also the possibility to tune the structure of hemicryptophanes to encapsulate selectively a targeted zwitterionic guest of biological interest.

As enantiopure hosts are very helpful in chiral recognition, asymmetric catalysis, and chirality sensing, ${ }^{2}$ we optically resolved the hemicryptophane racemates $( \pm)-1$ and $( \pm)-16$ using chiral HPLC (see the Supporting Information). In the case of ( \pm )-1, the two enantiomers were separated on a Chiralpak IA column $(250 \times 4.6 \mathrm{~mm})$ with an enantioselectivity of 1.52 and a resolution of 2.3 , using heptane/ethanol/ $\mathrm{CH}_{2} \mathrm{Cl}_{2}$ /triethylamine $(20 / 40 / 40 / 0.1)$ as the mobile phase. At preparative scale, after multiple injections on a Chiralpak IA column $(250 \times 10 \mathrm{~mm})$, around $80 \mathrm{mg}$ of each enantiomer was obtained in $12 \mathrm{~h}$ with ee values of $99 \%$ and $90 \%$ for the first and second eluted compounds, respectively. For $( \pm)-16$, the same eluent used with a Chiralpak ID column gave the two 
(a)

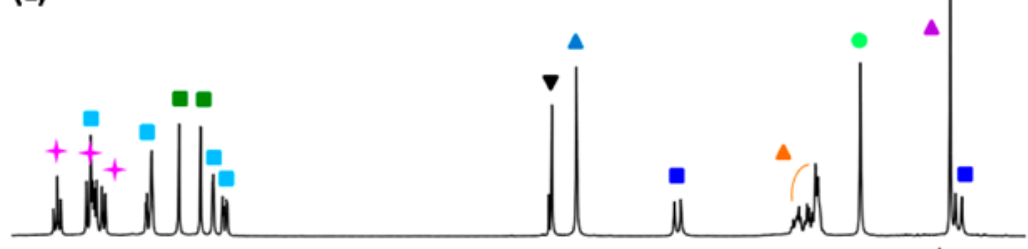

(b)

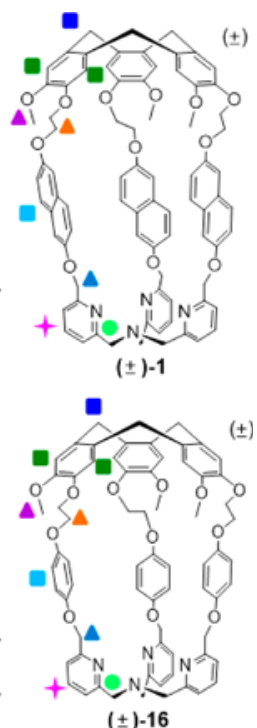

$\begin{array}{llllllll}7.4 & 6.8 & 6.2 & 5.6 & 5.0 & 4.4 & 3.8 & \mathrm{ppm}\end{array}$

$( \pm)-16$

Figure 2. ${ }^{1} \mathrm{H}$ NMR spectra $\left(500.1 \mathrm{MHz}, \mathrm{CD}_{2} \mathrm{Cl}_{2}, 298 \mathrm{~K}\right)$ of hemicryptophanes $( \pm)-\mathbf{1}(\mathrm{a})$ and $( \pm)-\mathbf{1 6}(\mathrm{b})$ and their protons assignment. $\boldsymbol{\nabla}=$ $\mathrm{CHDCl}_{2} ; \boldsymbol{\Delta}=\mathrm{Et}_{2} \mathrm{O}$.

Scheme 5. Synthesis of Hemicryptophane Complex Zn(II)@ 16

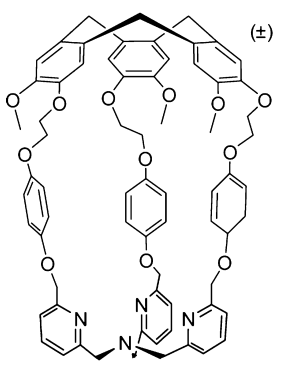

16

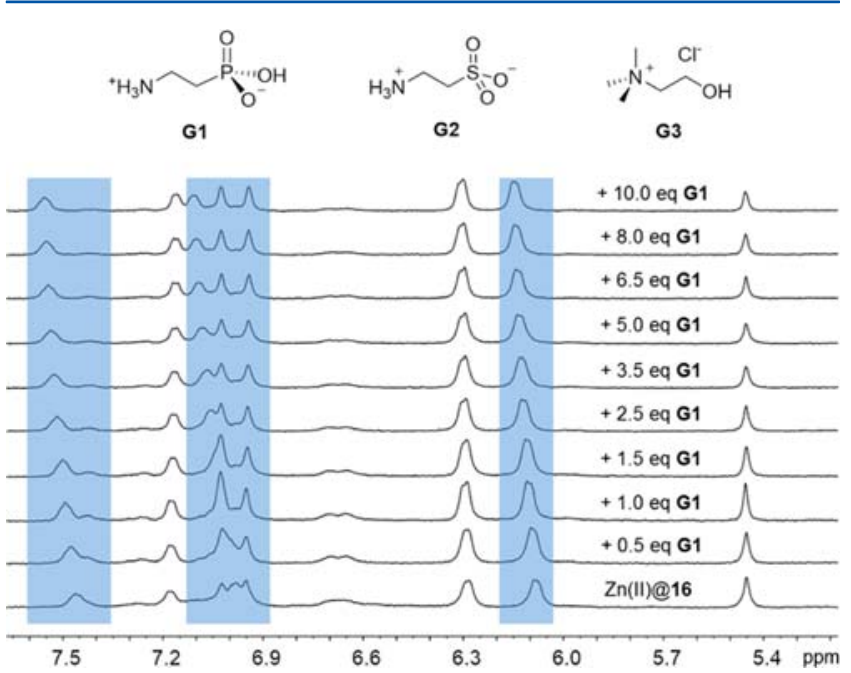

Figure 3. Zwitterionic guests $\mathbf{G 1 - G 3}$ tested in this work and ${ }^{1} \mathrm{H}$ NMR titration spectra $(500.1 \mathrm{MHz}, 298 \mathrm{~K})$ of $\mathrm{G1}$ with $1 \mathrm{mM}$ hemicryptophane host Zn(II)@16 in DMSO- $d_{6} / \mathrm{D}_{2} \mathrm{O}(80 / 20$, v/v).

enantiomers with an enantioselectivity of 1.51 and a resolution of 4.6 for the analytical separation. Preparative scale separation afforded around $50 \mathrm{mg}$ of each enantiomer with $e$ values $>99 \%$ in $3 \mathrm{~h}$. The absolute configuration of each enantiopure hemicryptophane was determined by ECD spectroscopy recorded in $\mathrm{CH}_{2} \mathrm{Cl}_{2}$ at $298 \mathrm{~K}$ by comparison with already assigned hemicryptophanes. ${ }^{20}$ As shown in Figure 4, in both cases, the spectra of the first eluted enantiomers exhibit a characteristic positive-negative bisignate curve from 230 to $250 \mathrm{~nm}$ corresponding to the $M$-configuration. The second eluted enantiomers show mirrored ECD signals allowing the assignment of the $P$-configuration. ${ }^{20}$

\section{CONCLUSION}

In summary, we have described the synthesis of two hemicryptophanes (1 and 16) belonging to a new class of TPA-based hemicryptophane cages. According to the metal binding abilities of the TPA units, these hemicryptophanes are chemical platforms available for various purposes and applications. This has been illustrated by the preparation of a $\mathrm{Zn}$ (II) complex and its subsequent use for the selective recognition of zwitterionic guests. Despite the 14 steps involved in the synthesis of each molecular cage, all the reactions are quite straightforward with relatively high yields. In particular, benefiting from a remarkable $90 \%$ yield for a triple macrocyclization reaction, gram-scale synthesis of hemicryptophane 16 was achieved. The racemate of each hemicryptophane can be readily resolved by chiral HPLC to give the enantiopure cages of which absolute configurations have been assigned by ECD spectroscopy. Currently, the preparation of metal complexes for these new cages, such as $\mathrm{Cu}(\mathrm{I})$ and $\mathrm{Fe}(\mathrm{II})$, and their applications in molecular recognition and supramolecular catalysis are being investigated and will be reported in due course.

\section{EXPERIMENTAL SECTION}

Methods and Materials. All reactions were carried out under argon by means of an inert gas/vacuum double manifold and standard Schlenk techniques. Dichloromethane was dried and degassed on a solvent station by passage through an activated alumina column followed by argon flush. Other solvents were dried prior to use over molecular sieves. ${ }^{1} \mathrm{H}$ and ${ }^{13} \mathrm{C}$ NMR spectra were recorded at 500.1 and 125.7 MHz, respectively, and $\delta$ chemical shifts are reported relative to the residual solvent signal. The HRMS-ESI mass spectra were 

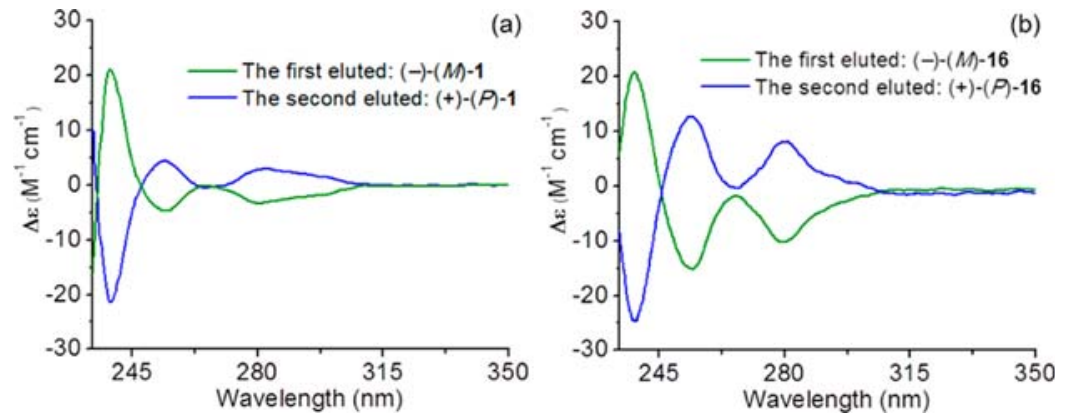

Figure 4. Experimental ECD spectra in $\mathrm{CH}_{2} \mathrm{Cl}_{2}$ at $298 \mathrm{~K}$ of the following: (a) (+)-(P)-1 (blue) and (-)-M-1 (green) and (b) (+)-(P)-16 (blue) and (-)-M-16 (green).

recorded in positive-ion mode (or negative) on a hybrid quadrupole time-of-flight mass spectrometer with an electrospray ionization (ESI) ion source. Specific rotations (in deg $\mathrm{cm}^{2} \mathrm{~g}^{-1}$ ) were measured in a 1 $\mathrm{dm}$ thermostated quartz cell on a Jasco-P1010 polarimeter. Circular dichroism spectra were recorded on a CD6 Jobin-Yvon dichrograph.

Synthesis of $\mathbf{8}$ and $\mathbf{9}$. Compound $\mathbf{8}$ was prepared starting from 2,6 pyridinedicarboxylic acid $\mathbf{2}$ according to the reported procedures. ${ }^{18,21}$ Compound 9 was synthesized according to the published procedure. ${ }^{22}$

Synthesis of 11. A solution of $9(100 \mathrm{mg}, 0.500 \mathrm{mmol}), 10(172$ $\mathrm{mg}, 0.500 \mathrm{mmol})$, and $\mathrm{Cs}_{2} \mathrm{CO}_{3}(244 \mathrm{mg}, 0.750 \mathrm{mmol})$ in DMF $(4$ $\mathrm{mL}$ ) was stirred for 2 days at $80{ }^{\circ} \mathrm{C}$ under argon. Then AcOEt (30 $\mathrm{mL})$ and $10 \%$ aqueous $\mathrm{NaOH}(30 \mathrm{~mL})$ were added. The organic layer was separated, and the aqueous phase was extracted with AcOEt $(2 \times$ $30 \mathrm{~mL}$ ). The combined organic layers were washed with $10 \%$ aqueous $\mathrm{NaOH}(2 \times 30 \mathrm{~mL})$ and dried over $\mathrm{Na}_{2} \mathrm{SO}_{4}$. After filtration, the organic solvent was removed under vacuum. The crude product was purified by column chromatography on silica gel with a 400:3 mixture of $\mathrm{CH}_{2} \mathrm{Cl}_{2}: \mathrm{MeOH}$ as eluent to give compound $\mathbf{1 1}$ as a light yellow solid (180 mg, $0.39 \mathrm{mmol}, 78 \%$ yield). ${ }^{1} \mathrm{H}$ NMR $\left(\mathrm{CDCl}_{3}, 298 \mathrm{~K}, 500.1\right.$ $\mathrm{MHz}): \delta 7.65(\mathrm{dd}, J=8.9,1.9 \mathrm{~Hz}, 2 \mathrm{H}) ; 7.21-7.14(\mathrm{~m}, 4 \mathrm{H}) ; 7.00-$ $6.93(\mathrm{~m}, 3 \mathrm{H}) ; 6.19-6.11(\mathrm{~m}, 1 \mathrm{H}) ; 5.50(\mathrm{dd} J=17.3,1.4 \mathrm{~Hz}, 1 \mathrm{H})$; $5.35(\mathrm{dd}, J=10.5,1.2 \mathrm{~Hz}, 1 \mathrm{H}) ; 4.76(\mathrm{~d}, J=11.7 \mathrm{~Hz}, 1 \mathrm{H}) ; 4.72(\mathrm{t}, J=$ $3.6 \mathrm{~Hz}, 1 \mathrm{H}) ; 4.66(\mathrm{~d}, J=5.3 \mathrm{~Hz}, 1 \mathrm{H}) ; 4.50-4.47(\mathrm{~m}, 5 \mathrm{H}) ; 3.98-3.91$ $(\mathrm{m}, 1 \mathrm{H}) ; 3.90(\mathrm{~s}, 3 \mathrm{H}) ; 3.60-3.56(\mathrm{~m}, 1 \mathrm{H}) ; 1.93-1.62(\mathrm{~m}, 6 \mathrm{H}) \mathrm{ppm}$. ${ }^{13} \mathrm{C}$ NMR $\left(\mathrm{CDCl}_{3}, 298 \mathrm{~K}, 125.7 \mathrm{MHz}\right): \delta 155.2(5), 155.1(9), 149.8$, $147.7,133.4,131.9,129.9,129.8,128.3,128.2,120.6,119.3(1)$ $119.2(8), 117.7,114.2,112.1,107.4,107.3,97.6,69.0,68.8,68.0,66.6$, $62.4,56.0,30.7,25.5,19.5 \mathrm{ppm}$. HRMS (ESI-TOF) $\mathrm{m} / z:[\mathrm{M}+\mathrm{Na}]^{+}$ Calcd for $\mathrm{C}_{28} \mathrm{H}_{32} \mathrm{NaO}_{6}$ 487.2091; Found 487.2077. $\mathrm{Mp}=99{ }^{\circ} \mathrm{C}$.

Synthesis of 12. In a $25 \mathrm{~mL}$ round-bottom flask, $11(750 \mathrm{mg}, 1.62$ $\mathrm{mmol}), \mathrm{Pd}(\mathrm{OAc})_{2}(7.3 \mathrm{mg}, 0.033 \mathrm{mmol}), \mathrm{PPh}_{3}(28.5 \mathrm{mg}, 0.110$ mmol), $\mathrm{NHEt}_{2}(25.1 \mathrm{mmol}), \mathrm{H}_{2} \mathrm{O}(2 \mathrm{~mL})$, and THF $(8 \mathrm{~mL})$ were mixed and stirred at $80^{\circ} \mathrm{C}$ under argon for $4 \mathrm{~h}$. Then the mixture was cooled to rt, and the solvents were removed under vacuum. AcOEt (10 $\mathrm{mL}$ ) was first added and then removed under vacuum twice. AcOEt $(200 \mathrm{~mL})$ and $\mathrm{H}_{2} \mathrm{O}(100 \mathrm{~mL})$ were then added. After thoroughly mixing, the organic layer was separated, and the aqueous phase was extracted with AcOEt $(2 \times 30 \mathrm{~mL})$. The combined organic layers were dried over $\mathrm{Na}_{2} \mathrm{SO}_{4}$, and the organic solvent was removed under vacuum. The crude product was purified by column chromatography on silica gel with a $20: 3$ mixture of $\mathrm{CH}_{2} \mathrm{Cl}_{2}$ : AcOEt as eluent to give compound 12 as a light yellow solid (600 mg, $1.41 \mathrm{mmol}, 88 \%$ yield). ${ }^{1} \mathrm{H}$ NMR $\left(\mathrm{CDCl}_{3}, 298 \mathrm{~K}, 500.1 \mathrm{MHz}\right): \delta 7.60(\mathrm{dd}, J=15.1,8.3 \mathrm{~Hz}$, $2 \mathrm{H}) ; 7.18-7.08(\mathrm{~m}, 4 \mathrm{H}) ; 7.00-6.93(\mathrm{~m}, 3 \mathrm{H}) ; 5.10(\mathrm{~s}, 1 \mathrm{H}) ; 4.76(\mathrm{~d}, J$ $=11.7 \mathrm{~Hz}, 1 \mathrm{H}) ; 4.72(\mathrm{t}, J=3.7 \mathrm{~Hz}, 1 \mathrm{H}) ; 4.50-4.43(\mathrm{~m}, 5 \mathrm{H})$; 3.99$3.94(\mathrm{~m}, 1 \mathrm{H}) ; 3.90(\mathrm{~s}, 3 \mathrm{H}) ; 3.61-3.57(\mathrm{~m}, 1 \mathrm{H}) ; 1.93-1.63(\mathrm{~m}, 6 \mathrm{H})$ ppm. ${ }^{13} \mathrm{C}$ NMR $\left(\mathrm{CDCl}_{3}, 298 \mathrm{~K}, 125.7 \mathrm{MHz}\right): \delta 155.1,152.0,149.7$, $147.7,131.8,130.0,129.6,128.5,127.8,120.6,119.6,118.1,114.1$, $112.1,109.7,107.2,97.7,68.8,67.9,66.5,62.4,56.0,30.7,25.5,19.5$ ppm. HRMS (ESI-TOF) $m / z:[\mathrm{M}+\mathrm{Na}]^{+}$Calcd for $\mathrm{C}_{25} \mathrm{H}_{28} \mathrm{NaO}_{6}$ 447.1778; Found 447.1763. $\mathrm{Mp}>70{ }^{\circ} \mathrm{C}$ (decomp.).

Synthesis of 13. In a $50 \mathrm{~mL}$ round-bottom flask, $8(100 \mathrm{mg}, 0.230$ $\mathrm{mmol}), 12(321 \mathrm{mg}, 0.757 \mathrm{mmol}), \mathrm{Cs}_{2} \mathrm{CO}_{3}(337 \mathrm{mg}, 1.04 \mathrm{mmol})$, and DMF $(10 \mathrm{~mL})$ were mixed and stirred at $90{ }^{\circ} \mathrm{C}$ for 3 days. Then the mixture was cooled to $\mathrm{rt}$, and DMF was removed under vacuum. $\mathrm{CH}_{2} \mathrm{Cl}_{2}(200 \mathrm{~mL})$ and $\mathrm{H}_{2} \mathrm{O}(200 \mathrm{~mL})$ were then added. After thoroughly mixing, the organic layer was separated, and the aqueous phase was extracted with $\mathrm{CH}_{2} \mathrm{Cl}_{2}(2 \times 50 \mathrm{~mL})$. The combined organic layers were dried over $\mathrm{Na}_{2} \mathrm{SO}_{4}$, and the organic solvent was removed under vacuum. The crude product was purified by column chromatography on silica gel with a $18: 1$ mixture of $\mathrm{CH}_{2} \mathrm{Cl}_{2}: \mathrm{MeOH}$ as eluent to give hemicryptophane precursor $\mathbf{1 3}$ as a yellow solid (330 $\mathrm{mg}, 0.207 \mathrm{mmol}$, 90\% yield). ${ }^{1} \mathrm{H} \mathrm{NMR}\left(\mathrm{CDCl}_{3}, 298 \mathrm{~K}, 500.1 \mathrm{MHz}\right): \delta$ $7.72-7.65(\mathrm{~m}, 6 \mathrm{H}) ; 7.61-7.56(\mathrm{~m}, 6 \mathrm{H}) ; 7.46(\mathrm{~d}, J=7.7 \mathrm{~Hz}, 3 \mathrm{H})$; $7.26(\mathrm{dd}, J=8.9,2.5 \mathrm{~Hz}, 3 \mathrm{H}) ; 7.20-7.16(\mathrm{~m}, 9 \mathrm{H}) ; 6.99-6.92(\mathrm{~m}$, $9 \mathrm{H}) ; 5.31(\mathrm{~s}, 6 \mathrm{H}) ; 4.75(\mathrm{~d}, J=11.7 \mathrm{~Hz}, 3 \mathrm{H}) ; 4.72(\mathrm{t}, J=3.5 \mathrm{~Hz}, 3 \mathrm{H})$; 4.49-4.44 (m, 15H); 4.01(s, 6H); 3.98-3.93 (m, 3H); 3.89 (s, 9H); $3.59-3.56(\mathrm{~m}, 3 \mathrm{H}) ; 1.90-1.54(\mathrm{~m}, 18 \mathrm{H}) \mathrm{ppm} .{ }^{13} \mathrm{C} \mathrm{NMR}\left(\mathrm{CDCl}_{3}\right.$, $298 \mathrm{~K}, 125.7 \mathrm{MHz}): \delta 159.1,156.7,155.3,155.0,149.8,147.7,137.3$, $131.9,129.9,129.8,128.3,121.8,120.6,119.6,119.3,119.1,114.2$, $112.1,107.8,107.3,97.6,70.8,68.8,67.9,66.6,62.4,60.3,56.0,30.7$, 25.5, $19.5 \mathrm{ppm}$. HRMS (ESI-TOF) $\mathrm{m} / \mathrm{z}:[\mathrm{M}+\mathrm{H}]^{+}$Calcd for $\mathrm{C}_{96} \mathrm{H}_{103} \mathrm{~N}_{4} \mathrm{O}_{18}$ 1599.7262; Found 1599.7249. $\mathrm{Mp}>64{ }^{\circ} \mathrm{C}$ (decomp.).

Synthesis of Hemicryptophane ( \pm )-1. A solution of hemicryptophane precursor $13(100 \mathrm{mg}, 63.0 \mu \mathrm{mol})$ in $\mathrm{CH}_{3} \mathrm{CN}(18 \mathrm{~mL})$ was added dropwise $(4 \mathrm{~h})$ under argon at $65{ }^{\circ} \mathrm{C}$ to a solution of $\mathrm{Sc}(\mathrm{OTf})_{3}(44 \mathrm{mg}, 88 \mu \mathrm{mol})$ in $\mathrm{CH}_{3} \mathrm{CN}(46 \mathrm{~mL})$. The mixture was stirred under argon at $65{ }^{\circ} \mathrm{C}$ for $24 \mathrm{~h}$. The solvent was then evaporated. The crude product was purified by column chromatography on silica gel with a 200:5:1 mixture of $\mathrm{CHCl}_{3}: \mathrm{MeOH}$ :triethylamine as eluent to give hemicryptophane $( \pm)-1$ as a light yellow solid ( $40 \mathrm{mg}, 88 \mu \mathrm{mol}, 49 \%$ yield). The crude product could be also used directly for the following resolution procedure.

Chiral HPLC Analysis for ( \pm )-1. On a Chiralpak IA column $(250 \times$ $4.6 \mathrm{~mm})$, with $1 \mathrm{~mL} \cdot \mathrm{min}^{-1}$ as flow-rate, heptane $/ \mathrm{EtOH} / \mathrm{CH}_{2} \mathrm{Cl}_{2} / \mathrm{TEA}$ $(20 / 40 / 40 / 0.1)$ as mobile phase, UV detection at $254 \mathrm{~nm}, \operatorname{Rt}(M-1)=$ 4.7 min, $\operatorname{Rt}(P-1)=5.6$ min, $\mathrm{k}(M-1)=0.59, \mathrm{k}(P-1)=0.90, \alpha=1.52$, and $\mathrm{Rs}=2.3$.

Resolution of Hemicryptophane ( \pm )-1. The crude product of $( \pm)-1(320 \mathrm{mg})$ was dissolved in $25 \mathrm{~mL}$ of $\mathrm{CH}_{2} \mathrm{Cl}_{2}$. On a Chiralpak IA column $(250 \times 10 \mathrm{~mm})$, with $5 \mathrm{~mL} \mathrm{~min}^{-1}$ as flow-rate, hexane/EtOH/ $\mathrm{CH}_{2} \mathrm{Cl}_{2} /$ TEA $(20 / 40 / 40 / 0.1)$ as mobile phase, UV detection at 254 $\mathrm{nm}, 210$ injections of $120 \mu \mathrm{L}$ were stacked every $3.5 \mathrm{~min}$. Both enantiomers were collected, and the solvent was then evaporated. The first eluted enantiomer ((-), M-1, $84 \mathrm{mg})$ was obtained with $99 \% e e$, and the second one $((+), P-1,73 \mathrm{mg})$ with $90 \%$ ee. $P-1:[\propto]_{D}^{25}:+38(c$ $\left.=0.114 ; \mathrm{CH}_{2} \mathrm{Cl}_{2}\right) ; M-1:[\propto]_{D}^{25}:-35\left(c=0.114 ; \mathrm{CH}_{2} \mathrm{Cl}_{2}\right) .{ }^{1} \mathrm{H}$ NMR $\left(\mathrm{CD}_{2} \mathrm{Cl}_{2}, 298 \mathrm{~K}, 500.1 \mathrm{MHz}\right): \delta 7.48(\mathrm{t}, J=7.7 \mathrm{~Hz}, 3 \mathrm{H}) ; 7.36-7.28$ $(\mathrm{m}, 12 \mathrm{H}) ; 7.10-7.08(\mathrm{~m}, 6 \mathrm{H}) ; 6.96(\mathrm{~s}, 3 \mathrm{H}) ; 6.86(\mathrm{~s}, 3 \mathrm{H}) ; 6.81(\mathrm{~d}, J=$ $2.3 \mathrm{~Hz}, 3 \mathrm{H}) ; 6.76(\mathrm{dd}, J=8.9,2.5 \mathrm{~Hz}, 3 \mathrm{H}) ; 5.24(\mathrm{~s}, 6 \mathrm{H}) ; 4.80(\mathrm{~d}, J=$ $13.7 \mathrm{~Hz}, 3 \mathrm{H})$; $4.30-4.19(\mathrm{~m}, 12 \mathrm{H}) ; 4.01(\mathrm{~s}, 6 \mathrm{H}) ; 3.62(\mathrm{~s}, 9 \mathrm{H}) ; 3.58$ $(\mathrm{d}, J=13.7 \mathrm{~Hz}, 3 \mathrm{H}) \mathrm{ppm} .{ }^{13} \mathrm{C} \mathrm{NMR}\left(\mathrm{CD}_{2} \mathrm{Cl}_{2}, 298 \mathrm{~K}, 125.7 \mathrm{MHz}\right): \delta$ $158.8,156.6,154.9$, 154.6, 148.7, 146.9, 136.8, 133.1, 132.0, 129.7, $129.6,128.1,128.0,122.2,119.5,119.2,118.9,118.7,116.6,113.9$, 108.4, 107.4, 70.9, 68.2, 66.7, 60.6, 56.0, 36.2 ppm. For COSY, HSQC, and HMBC, see the Supporting Information. HRMS (ESI-TOF) $\mathrm{m} / \mathrm{z}$ : 
$[\mathrm{M}+\mathrm{H}]^{+}$Calcd for $\mathrm{C}_{81} \mathrm{H}_{73} \mathrm{~N}_{4} \mathrm{O}_{12}$ 1293.5220; Found 1293.5202. $\mathrm{Mp}>$ $250{ }^{\circ} \mathrm{C}$ (decomp.).

Synthesis of 15. In a $100 \mathrm{~mL}$ round-bottom flask, $8(225 \mathrm{mg}, 0.516$ $\mathrm{mmol}), 14(638 \mathrm{mg}, 1.70 \mathrm{mmol}), \mathrm{Cs}_{2} \mathrm{CO}_{3}(757 \mathrm{mg}, 2.32 \mathrm{mmol})$, and DMF $(22 \mathrm{~mL})$ were mixed and stirred at $90{ }^{\circ} \mathrm{C}$ for 3 days. Then the mixture was cooled to rt, and DMF was removed under vacuum. Then $300 \mathrm{~mL} \mathrm{CH}_{2} \mathrm{Cl}_{2}$ and $300 \mathrm{~mL} \mathrm{H}_{2} \mathrm{O}$ were added. After thoroughly mixing, the organic layer was separated, and the aqueous phase was extracted with $\mathrm{CH}_{2} \mathrm{Cl}_{2}(2 \times 100 \mathrm{~mL})$. The combined organic layers were dried over $\mathrm{Na}_{2} \mathrm{SO}_{4}$, and the organic solvent was removed under vacuum. The crude product was purified by column chromatography on silica gel with a 25:1 mixture of $\mathrm{CH}_{2} \mathrm{Cl}_{2}: \mathrm{MeOH}$ as eluent to give hemicryptophane precursor $\mathbf{1 5}$ as a white solid $(728 \mathrm{mg}, 0.504 \mathrm{mmol}$, $98 \%$ yield $).{ }^{1} \mathrm{H}$ NMR $\left(\mathrm{CDCl}_{3}, 298 \mathrm{~K}, 500.1 \mathrm{MHz}\right): \delta 7.70(\mathrm{t}, J=7.8$ $\mathrm{Hz}, 3 \mathrm{H}) ; 7.55(\mathrm{~d}, J=7.7 \mathrm{~Hz}, 3 \mathrm{H}) ; 7.40(\mathrm{~d}, J=7.7 \mathrm{~Hz}, 3 \mathrm{H}) ; 6.96-6.88$ $(\mathrm{m}, 21 \mathrm{H}) ; 5.15(\mathrm{~s}, 6 \mathrm{H}) ; 4.75(\mathrm{~d}, J=11.8 \mathrm{~Hz}, 3 \mathrm{H}) ; 4.71(\mathrm{t}, J=3.5 \mathrm{~Hz}$, $3 \mathrm{H}) ; 4.47(\mathrm{~d}, J=11.8 \mathrm{~Hz}, 3 \mathrm{H}) ; 4.36(\mathrm{t}, J=5.0 \mathrm{~Hz}, 6 \mathrm{H}) ; 4.30(\mathrm{t}, J=$ $5.0 \mathrm{~Hz}, 6 \mathrm{H}) ; 3.98-3.89(\mathrm{~m}, 9 \mathrm{H}) ; 3.88(\mathrm{~s}, 9 \mathrm{H}) ; 3.60-3.55(\mathrm{~m}, 3 \mathrm{H})$; $1.91-1.54(\mathrm{~m}, 18 \mathrm{H}) \mathrm{ppm} .{ }^{13} \mathrm{C}$ NMR $\left(\mathrm{CDCl}_{3}, 298 \mathrm{~K}, 125.7 \mathrm{MHz}\right): \delta$ $159.0,156.9,153.1,152.9,149.8,147.7,137.2,131.8,121.6,120.6$, $119.5,116.1,116.0,115.8,115.7,114.1,112.1,97.6,71.3,68.8,68.0$, $67.2,62.3,56.0,30.7,25.5,19.5$ ppm. HRMS (ESI-TOF) $\mathrm{m} / \mathrm{z}$ : $[\mathrm{M}+$ $\mathrm{H}]^{+}$Calcd for $\mathrm{C}_{84} \mathrm{H}_{97} \mathrm{~N}_{4} \mathrm{O}_{18}$ 1449.6792; Found 1449.6768. Mp > 70 ${ }^{\circ} \mathrm{C}$ (decomp.).

Synthesis of Hemicryptophane ( \pm )-16. In a $2 \mathrm{~L}$ round-bottom flask, the hemicryptophane precursor $15(1.45 \mathrm{~g}, 1.00 \mathrm{mmol})$, $\mathrm{HCOOH}(1 \mathrm{~L})$ and $\mathrm{CH}_{2} \mathrm{Cl}_{2}(10 \mathrm{~mL})$ were added. The mixture was stirred at $\mathrm{rt}$ for 2 days. Then $\mathrm{HCOOH}$ was removed under vacuum, and yellow oil was obtained. $\mathrm{CH}_{2} \mathrm{Cl}_{2}(100 \mathrm{~mL})$ and TEA $(5 \mathrm{~mL})$ were added and then evaporated. Finally $\mathrm{CH}_{2} \mathrm{Cl}_{2}(3 \mathrm{~mL})$ was added to fully solubilize the crude product followed by the addition of $\mathrm{Et}_{2} \mathrm{O}(300$ $\mathrm{mL}$ ) to precipitate the product. After filtration and washing with $\mathrm{Et}_{2} \mathrm{O}$, the pure $( \pm)-16$ was obtained as a white solid $(1.03 \mathrm{~g}, 0.900 \mathrm{mmol}$, $90 \%$ yield).

Chiral HPLC Analysis for ( \pm )-16. On Chiralpak ID column $(250 \times$

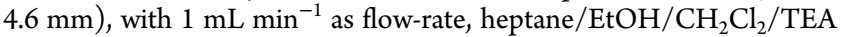
$(20 / 40 / 40 / 0.1)$ as mobile phase, UV detection at $254 \mathrm{~nm}, \mathrm{Rt}(M-16)$ $=8.7$ min, $\operatorname{Rt}(P-16)=11.7 \min , \mathrm{k}(M-16)=1.92, \mathrm{k}(P-16)=2.90, \alpha=$ 1.51 , and $\mathrm{Rs}=4.6$.

Resolution of Hemicryptophane ( \pm )-16. The pure product of $( \pm)-16(100 \mathrm{mg})$ was dissolved in $5.2 \mathrm{~mL}$ of $\mathrm{CH}_{2} \mathrm{Cl}_{2}$. On a Chiralpak ID column $(250 \times 10 \mathrm{~mm})$, with $5 \mathrm{~mL} \mathrm{~min}{ }^{-1}$ as flow-rate, hexane/ $\mathrm{EtOH} / \mathrm{CH}_{2} \mathrm{Cl}_{2} / \mathrm{TEA}(20 / 40 / 40 / 0.1)$ as mobile phase, UV detection at $300 \mathrm{~nm}, 26$ injections of $200 \mu \mathrm{L}$ were stacked every $7.2 \mathrm{~min}$. Both enantiomers were collected, and the solvent was then evaporated. The first eluted enantiomer $((-), M-16,46 \mathrm{mg})$ and the second one $((+)$, $P$-16, $48 \mathrm{mg}$ ) were obtained with both ee values $>99 \%$. P-16: $[\propto]_{D}^{25}$ : $+52\left(c=0.27 ; \mathrm{CH}_{2} \mathrm{Cl}_{2}\right) ; M-16:[\propto]_{D}^{25}:-52\left(c=0.25 ; \mathrm{CH}_{2} \mathrm{Cl}_{2}\right) .{ }^{1} \mathrm{H}$ $\operatorname{NMR}\left(\mathrm{CD}_{2} \mathrm{Cl}_{2}, 298 \mathrm{~K}, 500.1 \mathrm{MHz}\right): \delta 7.56(\mathrm{t}, J=7.7 \mathrm{~Hz}, 3 \mathrm{H}) ; 7.34$ (d, $J=7.4 \mathrm{~Hz}, 3 \mathrm{H}) ; 7.22(\mathrm{~d}, J=7.7 \mathrm{~Hz}, 3 \mathrm{H}) ; 6.90(\mathrm{~s}, 3 \mathrm{H}) ; 6.82(\mathrm{~s}$, $3 \mathrm{H}) ; 6.70(\mathrm{~d}, J=9.0 \mathrm{~Hz}, 6 \mathrm{H}) ; 6.56(\mathrm{~d}, J=9.0 \mathrm{~Hz}, 6 \mathrm{H}) ; 5.08(\mathrm{~s}, 6 \mathrm{H})$; $4.75(\mathrm{~d}, J=13.7 \mathrm{~Hz}, 3 \mathrm{H}) ; 4.27-4.23(\mathrm{~m}, 3 \mathrm{H}) ; 4.19-4.15(\mathrm{~m}, 3 \mathrm{H})$; $4.09-4.03(\mathrm{~m}, 6 \mathrm{H}) ; 3.97-3.90(\mathrm{~m}, 6 \mathrm{H}) ; 3.66(\mathrm{~s}, 9 \mathrm{H}) ; 3.54(\mathrm{~d}, J=$ $13.7 \mathrm{~Hz}, 3 \mathrm{H})$ ppm. ${ }^{13} \mathrm{C}$ NMR $\left(\mathrm{CD}_{2} \mathrm{Cl}_{2}, 298 \mathrm{~K}, 125.7 \mathrm{MHz}\right): \delta 158.7$, $156.8,152.6,148.8,146.7,136.8,133.1,131.9,122.2,119.4,116.7$, $115.7,115.6,113.8,71.2,68.2,67.2,60.5,56.0,36.1 \mathrm{ppm}$. For COSY, HSQC, and HMBC, see the Supporting Information. HRMS (ESITOF) $m / z:[\mathrm{M}+2 \mathrm{H}]^{2+}$ Calcd for $\mathrm{C}_{69} \mathrm{H}_{68} \mathrm{~N}_{4} \mathrm{O}_{12}$ 572.2411; Found 572.2398. $\mathrm{Mp}=260^{\circ} \mathrm{C}$.

Synthesis of the Racemic Hemicryptophane Complex Zn(II)@16. To a solution of $( \pm)-16(47 \mathrm{mg}, 0.041 \mathrm{mmol})$ in $4 \mathrm{~mL} \mathrm{CHCl}, 12 \mu \mathrm{L}$ triethylamine was added under argon followed by addition of the solution of $\mathrm{Zn}\left(\mathrm{ClO}_{4}\right)_{2}\left(\mathrm{H}_{2} \mathrm{O}\right)_{6}(15 \mathrm{mg}, 0.041 \mathrm{mmol}, 1$ equiv $)$ in $2.5 \mathrm{~mL}$ $\mathrm{CH}_{3} \mathrm{OH}$. After stirring the reaction mixture at room temperature for 4 $\mathrm{h}$, a large amount of precipitate appeared. The precipitate was collected, washed thoroughly with $\mathrm{Et}_{2} \mathrm{O}$, and dried under vacuum to give the pure complex as a white solid $(33 \mathrm{mg}, 0.023 \mathrm{mmol}, 57 \%$ yield). The ${ }^{1} \mathrm{H}$ NMR spectrum of $\mathrm{Zn}(\mathrm{II}) @ 16$ exhibits complex and broad signals because of the conformational rigidification of the whole structure induced by the metal complexation that gives different isomers, which is similar as the previously reported Zn(II)@ Hemicryptophane complex. ${ }^{4 \mathrm{~b}}$ For the detailed spectra of ${ }^{1} \mathrm{H}$ NMR, ${ }^{13} \mathrm{C}$ NMR, COSY, HSQC, and HMBC, see the Supporting Information. HRMS (ESI-TOF) $m / z:\left[\mathrm{M}+\mathrm{HCOO}^{+}\right.$Calcd for

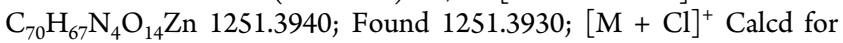
$\mathrm{C}_{69} \mathrm{H}_{66} \mathrm{ClN}_{4} \mathrm{O}_{12} \mathrm{Zn} \mathrm{1241.3652;} \mathrm{Found} \mathrm{1241.3640.} \mathrm{Mp}>220{ }^{\circ} \mathrm{C}$ (decomp.).

\section{ACKNOWLEDGMENTS}

D.Z. acknowledges grants from the China Scholarship Council, the Région Auvergne-Rhône-Alpes, France, for an Accueil Doc Bursary, and ENS-Lyon for an Attractiveness Fellowship for Ph.D studies. A.M. thanks ANR OH-risque for funding, grant number ANR-14-OHRI-0015-01.

\section{REFERENCES}

(1) (a) Zhang, D.; Martinez, A.; Dutasta, J. P. Chem. Rev. 2017, 117, 4900. (b) Ajami, D.; Liu, L. J.; Rebek, J., Jr. Chem. Soc. Rev. 2015, 44, 490. (c) Zarra, S.; Wood, D. M.; Roberts, D. A.; Nitschke, J. R. Chem. Soc. Rev. 2015, 44, 419. (d) Brown, C. J.; Toste, F. D.; Bergman, R. G.; Raymond, K. N. Chem. Rev. 2015, 115, 3012. (e) Raynal, M.; Ballester, P.; Vidal-Ferran, A.; van Leeuwen, P. W. N. M. Chem. Soc. Rev. 2014, 43, 1660. (f) Blanco, V.; Leigh, D. A.; Marcos, V. Chem. Soc. Rev. 2015, $44,5341$.

(2) Hembury, G. A.; Borovkov, V. V.; Inoue, Y. Chem. Rev. 2008, $108,1$.

(3) (a) Wiester, M. J.; Ulmann, P. A.; Mirkin, C. A. Angew. Chem., Int. Ed. 2011, 50, 114. (b) Jaeger, K. E.; Eggert, T. Curr. Opin. Biotechnol. 2004, 15, 305. (c) Raynal, M.; Ballester, P.; Vidal-Ferran, A.; van Leeuwen, P. W. N. M. Chem. Soc. Rev. 2014, 43, 1734.

(4) (a) Chatelet, B.; Payet, E.; Perraud, O.; Dimitrov-Raytchev, P.; Chapellet, L. L.; Dufaud, V.; Martinez, A.; Dutasta, J. P. Org. Lett. 2011, 13, 3706. (b) Zhang, D. W.; Gao, G. H.; Guy, L.; Robert, V.; Dutasta, J. P.; Martinez, A. Chem. Commun. 2015, 51, 2679.

(5) (a) Gautier, A.; Mulatier, J. C.; Crassous, J.; Dutasta, J. P. Org. Lett. 2005, 7, 1207. (b) Zhang, D. W.; Mulatier, J. C.; Cochrane, J. R.; Guy, L.; Gao, G. H.; Dutasta, J. P.; Martinez, A. Chem. - Eur. J. 2016, 22, 8038.

(6) (a) Muhldorf, B.; Wolf, R. Angew. Chem., Int. Ed. 2016, 55, 427. (b) Oloo, W. N.; Fielding, A. J.; Que, L. J. Am. Chem. Soc. 2013, 135, 6438.

(7) (a) Isse, A. A.; Visona, G.; Ghelfi, F.; Roncaglia, F.; Gennaro, A. Adv. Synth. Catal. 2015, 357, 782. (b) Eckenhoff, W. T.; Biernesser, A. B.; Pintauer, T. Inorg. Chem. 2012, 51, 11917. (c) Pan, X. C.; Malhotra, N.; Simakova, A.; Wang, Z. Y.; Konkolewicz, D.; Matyjaszewski, K. J. Am. Chem. Soc. 2015, 137, 15430.

(8) (a) Badetti, E.; Wurst, K.; Licini, G.; Zonta, C. Chem. - Eur. J. 2016, 22, 6515. (b) Scaramuzzo, F. A.; Licini, G.; Zonta, C. Chem. - 
Eur. J. 2013, 19, 16809. (c) Zhiquan, L.; Polen, S.; Hadad, C. M.; RajanBabu, T. V.; Badjic, J. D. J. Am. Chem. Soc. 2016, 138, 8253.

(9) (a) Wang, H. Y.; Mijangos, E.; Ott, S.; Thapper, A. Angew. Chem., Int. Ed. 2014, 53, 14499. (b) Woods, T. J.; Ballesteros-Rivas, M. F.; Ostrovsky, S. M.; Palii, A. V.; Reu, O. S.; Klokishner, S. I.; Dunbar, K. R. Chem.-Eur. J. 2015, 21, 10302.

(10) (a) Chatelain, L.; Walsh, J. P. S.; Pecaut, J.; Tuna, F.; Mazzanti, M. Angew. Chem., Int. Ed. 2014, 53, 13434. (b) Aratani, Y.; Yamada, Y.; Fukuzumi, S. Chem. Commun. 2015, 51, 4662.

(11) (a) Sawaki, T.; Ishizuka, T.; Kawano, M.; Shiota, Y.; Yoshizawa, K.; Kojima, T. Chem.-Eur. J. 2013, 19, 8978. (b) Weisser, F.; Stevens, H.; Klein, J.; van der Meer, M.; Hohloch, S.; Sarkar, B. Chem. - Eur. J. 2015, 21, 8926.

(12) (a) Kotani, H.; Sugiyama, T.; Ishizuka, T.; Shiota, Y.; Yoshizawa, K.; Kojima, T. J. Am. Chem. Soc. 2015, 137, 11222. (b) Desnoyer, A. N.; Behyan, S.; Patrick, B. O.; Dauth, A.; Love, J. A.; Kennepohl, P. Inorg. Chem. 2016, 55, 13.

(13) Saad, F. A.; Knight, J. C.; Kariuki, B. M.; Amoroso, A. J. Dalton Trans. 2016, 45, 10280.

(14) Andrez, J.; Bozoklu, G.; Nocton, G.; Pecaut, J.; Scopelliti, R.; Dubois, L.; Mazzanti, M. Chem.-Eur. J. 2015, 21, 15188.

(15) Ngo, H. T.; Liu, X. J.; Jolliffe, K. A. Chem. Soc. Rev. 2012, 41, 4928.

(16) (a) Canary, J. W.; Mortezaei, S.; Liang, J. A. Coord. Chem. Rev. 2010, 254, 2249. (b) Canary, J. W. Chem. Soc. Rev. 2009, 38, 747.

(17) (a) You, L.; Berman, J. S.; Anslyn, E. V. Nat. Chem. 2011, 3, 943. (b) Joyce, L. A.; Maynor, M. S.; Dragna, J. M.; da Cruz, G. M.; Lynch, V. M.; Canary, J. W.; Anslyn, E. V. J. Am. Chem. Soc. 2011, 133, 13746. (c) Jo, H. H.; Edupuganti, R.; You, L.; Dalby, K. N.; Anslyn, E. V. Chem. Sci. 2015, 6, 158.

(18) Zeng, X. S.; Coquiere, D.; Alenda, A.; Garrier, E.; Prange, T.; Li, Y.; Reinaud, O.; Jabin, I. Chem.-Eur. J. 2006, 12, 6393.

(19) (a) Perraud, O.; Robert, V.; Martinez, A.; Dutasta, J. P. Chem. Eur. J. 2011, 17, 13405. (b) Perraud, O.; Robert, V.; Gornitzka, H.; Martinez, A.; Dutasta, J. P. Angew. Chem., Int. Ed. 2012, 51, 504. (c) Schmitt, A.; Robert, V.; Dutasta, J. P.; Martinez, A. Org. Lett. 2014, 16, 2374.

(20) (a) Schmitt, A.; Perraud, O.; Payet, E.; Chatelet, B.; Bousquet, B.; Valls, M.; Padula, D.; Di Bari, L.; Dutasta, J. P.; Martinez, A. Org. Biomol. Chem. 2014, 12, 4211. (b) Perraud, O.; Dimitrov-Raytchev, P.; Martinez, A.; Dutasta, J. P. Chirality 2010, 22, 88. (c) Cochrane, J. R.; Schmitt, A.; Wille, U.; Hutton, C. A. Chem. Commun. 2013, 49, 8504. (d) Canceill, J.; Collet, A.; Gabard, J.; Gottarelli, G.; Spada, G. P. J. Am. Chem. Soc. 1985, 107, 1299. (e) Canceill, J.; Collet, A.; Gottarelli, G.; Palmieri, P. J. Am. Chem. Soc. 1987, 109, 6454.

(21) Liu, X.; Bouwman, E. Polyhedron 2016, 118, 25.

(22) Hau, S. C. K.; Cheng, P. S.; Mak, T. C. W. Polyhedron 2013, 52, 992. 